\title{
TOURISTS' PERCEPTION: THE CASE OF OHRID, MACEDONIA
}

DOI: https://doi.org/10.18509/AGB.2019.09

UDC: $338.48-2-052(497.771)$

\section{Biljana Petrevska}

Faculty of Tourism and Business Logistics, Goce Delcev University - Stip, Macedonia

corresponding author: biljana.petrevska@ugd.edu.mk

submitted: 28.03 .2018

accepted: 21.06.2018

published: 18.01 .2019

\begin{abstract}
The aim of this study is to determine the factors that affect tourists on creating their images and perceptions while experiencing Ohrid, the most famous tourist destination in Macedonia. In this regard, the presence and affection of five factors was investigated: (i) Perception of place; (ii) Pull motives; (iii) Perception of safety; (iv) Type of experience; and (v) Fulfilled expectations. The analysis was based on face-to-face survey conducted with 500 tourists in June-August 2016. Generally, the findings indicate many suggestions and recommendations for tourism-policy makers. Towards the perception of the place, tourists found the sampled locations to be historic, legendary and religious places, which do not serve just as tourist places for sightseeing. As for the pull factors, the cultural heritage was perceived as attraction that brought tourists to the surveyed locations. Towards the perception of safety, Ohrid and Macedonia were perceived as fully safe and secure for tourism. Based on Cohen's (1979) classification of tourists, the results revealed that recreational tourists are the dominant group visiting Ohrid, followed by the existential, experiential, and experimental types of tourists, while the diversionary tourists were virtually absent. Finally, the surveyed tourists found highly fulfilled expectations evaluating Ohrid as destination worth visiting which gave a value to their money. The findings in this study may serve as a valuable starting point in creating new strategic approaches that may support tourism development in Ohrid and Macedonia.
\end{abstract}

Key words: tourist types, motives, Ohrid, tourism development.

\section{INTRODUCTION}

The issue of perception by tourists and visitors is highly important since it enables tourism policymakers to create new insights and tailor new strategic approaches that may increase the number of visits and night spent in the destination. While tourists' motivation is widely explored topic, the determining factors that affect tourists on creating images and perceptions has been somewhat unexplored research topics.

The primary objective of the study is to provide evidence on prevailing perceptions to create tourist image. This issue will be studied on the case of Ohrid, Macedonia. Ohrid represents a suitable test ground for investigating tourists' perception since it is the most famous tourist destination in Macedonia with 234,361 tourists and 830,333 overnights in 2016, this encompassed $27 \%$ of all arrivals and $34 \%$ of all overnight in Macedonia that year [19]. Additionally, to our best knowledge, no academic studies have dealt with this topic. Hence, this is the first attemt to identify the presence and affection of factors that affect tourists to create tourist image of Ohrid. The practical contribution of the paper lies in the recommendations that may serve as a valuable starting point in creating new strategic approaches that may support tourism development in Ohrid and Macedonia.

As for the organization of the paper, after the introduction, section two provides a snapshot on the literature review on tourist typology, as a background material. The applied methodology is presented in section three, while the findings and discussion are noted in section four. Section four presents the conclusion and recommendations, while the main limitation of the research and some future steps to be addressed, are noted in the last section of the paper. 


\section{BACKGROUND MATERIAL}

It is more than obvious that the tourist will create certain image about the destination depending on the preferences. Although may sound fragile, but the vast majority of today's tourists know exactly what they are looking for. Yet, they are very demanding and have complex, multi-layered desires and needs. Today's so called "postmodern tourists" have specific interests and individual motives which results in tailored made tourist products according to their particular preferences. They are often highly experienced in travelling and demand perfect tourism products rather than standardized ones.

The literature contains a large body of work discussing tourist roles in order to define their considerable variations. Mostly, the behavior is related to specific demographic and background characteristics emphasizing the life course as the leading component for investigating tourist role preferences. Yet, attention should be paid to a variety of social structures and processes, including psychological needs and life-course stage. Cohen [2] was one of the first sociologists who proposed a typology to conceptually clarify the term "tourist" by developing a four-fold typology. Few years later, Cohen [3] expended the list by suggesting a five-

\section{METHODOLOGY}

In order to identify the main factors that affect tourists on creating images and perceptions while experiencing Ohrid, the research took qualitativeand quantitative methods. The qualitative approach included review of literature and analysis of relevant publications. The quantitative approach covered data obtained from a face-to-face surveyconducted among 500 tourists in June-August 2016. A questionnaire was developed for foreign anddomestic tourists that visited Ohrid on two locations: the monastery of St. Naum $(30 \mathrm{~km}$ fromOhrid near the border with Albania) and the church of Ss. Clement and Panteleimon at Plaosnik(located in the old part of the city center). The tourists were previously well informed about the survey's aim in order to avoid any attempt tomanipulate the survey process and possibly bias the results. A schedule was established whereby data were collected during different days of the week and at different times of the day to maximize the chances of obtaining a representative sample. Prior to entering the field survey, the piloting was performed in order to check the validity of the questionnaire.

The survey instrument was a self-administered fixed-choice questionnaire. Respondents used a five point Likert scale (1=strongly disagree to $5=$ strongly agree) to judge the importance of each group classification of tourists, based on the type of experience they were seeking.

Pearce [14] identified specific behavior linking the evolutionary nature of tourist role preference and the psychological needs. Moreover, he developed 15 different tourist types which allowed creation of several measurement scales. In this respect, the Tourist Roles Preference Scale [22] presents a comprehensive classification of leisure tourists. Additional work resulted in adding two more tourist types to the tourist categorization [5]. A prior work that is related to the typology of Yiannakis and Gibson [22], is noted by Mo et al., [13] by designing International Tourist Role scale. Upon this scale, Keng and Cheng [9] and Jiang et al., [8] found that novelty seeking is related to choice of tourist role. Furthermore, a cluster analysis is offered by Ryan and Glendon [17] being derived from the Leisure Motivation Scale previously introduced by Beard and Ragheb [1].

Further on, researchers focused on exploring the experience of tourists as well as the importance of the tourist experience for tourists [23], along with classification of tourists according to the degree of novelty and familiarity sought [10].

factor. The questions were structured in six section, as follows:

Section I contained nine questions referring general data of the respondents (gender, age, marital status, country of origin, education, type of visitor, type of holiday and frequency of visit);

Section II comprised of three questions defining the perception of place;

Section III comprised of three questions identifying the 'pull' motives;

Section IV encompassed three questions diagnosing tourist perception for safety;

Section V had a set of five questions defining tourist type (based on classification proposed by Cohen [2]); and

Section VI included three questions describing fulfilled expectations.

A total of 500 copies of the questionnaire were distributed, out of which 382 were deemed complete and usable, thus having response rate of $76.4 \%$. The collected data were transferred to a common scorecard database in SPSS 24.0 in order to perform the statistical evaluation. Some descriptive statistics and nonparametric statistical tests were used for creating an initial tourist type for Ohrid among domestic and foreign tourists. In order to identify the possible relationship between the 
variables, the Chi-Square test $\left(\chi^{2}\right)$ for independence was calculated.

\section{FINDINGS AND DISCUSSION}

The findings are presented in a twofold manner. The first part discusses the general findings and discussion on the specific data. This means that each of the 26 questions that comprised the questionnaire was separately analyzed, whereas, the general data in accordance to the suggested categorization, while the specific data (17 questions) in accordance to a five-point Likert scale. The second part discusses findings based on cross-tabulations of general data versus specific data in order to discover a presence of association between the variables.

\section{Specific data findings}

Table 1 presents the demographic attributes of respondents according to nine questions from the first section of the questionnaire (gender, age, marital status, country of origin, education, type of visitor, type of holiday and frequency of visit). It is noticeable a slight difference in favor of female respondents (54\% vs. $45 \%$ ). According to the age classification, most of the respondents (43\%) belong to the group $30-49$ years, followed by the elderly tourists of 50 years and over (32\%), while the younger tourists (age 20-29) represent 25\%.

With regards to the marital status, the vast majority of respondents are married (63\%). As per country of origin, $57 \%$ of the surveyed tourists are domestic, while $43 \%$ are foreigners. According to the level of education, the dominant group of respondents (69\%) hold university diploma, and the same percentage stands for being employed. Having in mind that the survey was conducted at two very famous and top-visited tourist location in Ohrid, which simultaneously represent religious places, the questionnaire contained a question on the type of visitor. Unsurprisingly, it was found that $71 \%$ are tourists, but surprisingly $19 \%$ of the respondents declared to be pilgrims, and even $10 \%$ replied to belong to the category "other" without specifying the meaning. Majority of the respondents are individual tourists who came by a self-organized visit (70\%), vs. $30 \%$ who came on arranged tour by a travel agency. According to the frequency of visit, $45 \%$ of the respondents visited Ohrid more than five times so far. Yet, it is interesting to note that one/third (33\%) of the visitors are newcomers meaning they visited Ohrid for the first time.

Table 1. Descriptive statistics on general data $\left(\sum=382\right)$

\begin{tabular}{|c|c|c|c|}
\hline Item & $\%$ & Item & $\%$ \\
\hline Gender & & Occupation status & \\
\hline Male & 46.1 & Student & 12.6 \\
\hline Female & 53.9 & Employed & 68.6 \\
\hline Age & & Unemployed & 6.3 \\
\hline $20-29$ & 24.6 & Retired & 12.6 \\
\hline $30-49$ & 42.9 & Type of visitor & \\
\hline $50+$ & 32.5 & Pilgrim & 18.8 \\
\hline Marital status & & Tourist & 71.2 \\
\hline Married & 62.3 & Other & 9.9 \\
\hline Single & 13.6 & Type of holiday & \\
\hline Divorced & 4.7 & Individual (self-organized) & 69.6 \\
\hline With partner & 15.7 & Group (by travel agency) & 30.4 \\
\hline Other & 3.7 & Frequency of visit & \\
\hline Country of origin & & First time & 33.0 \\
\hline Domestic tourist & 56.5 & Second time & 8.4 \\
\hline Foreign tourist & 43.5 & 3-5 times & 13.6 \\
\hline Education & & More than 5 times & 45.0 \\
\hline Elementary & 4.2 & & \\
\hline High & 27.2 & & \\
\hline Graduate & 68.6 & & \\
\hline
\end{tabular}

to be historic, legendary and religious places, which

The second section comprised of three questions defining the perception of place. The summarized findings are presented in Table 2. It may be concluded that tourists found the sampled locations do not serve just as tourist places for sightseeing.

This supports other complementary findings about the tourist types and pull motives. Section three of the questionnaire comprised of three questions 
identifying the 'pull' motives. Based on the experiential approach, we identified three factors that may attract tourists to visit Ohrid: cultural heritage, religion and sightseeing. After analyzing the results, it was found that the cultural heritage was perceived as attraction that brought tourists to the surveyed locations. This finding stands along with the second most tourist type being identified for Ohrid.

Table 2. Summarized findings on perception of place

\begin{tabular}{|c|c|c|c|c|c|c|c|c|}
\hline \multirow[b]{2}{*}{$\begin{array}{l}\stackrel{\Xi}{0} \\
\stackrel{0}{0} \\
\stackrel{0}{0}\end{array}$} & \multirow[b]{2}{*}{ Specific questions } & \multicolumn{5}{|c|}{$\%$} & \multirow[b]{2}{*}{ 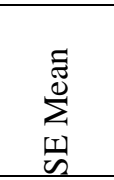 } & \multirow[b]{2}{*}{ 总 } \\
\hline & & 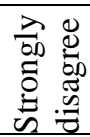 & 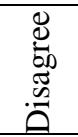 & 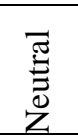 & $\underset{\square}{\mathbb{d}}$ & 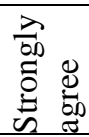 & & \\
\hline \multirow{3}{*}{ 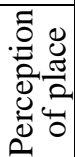 } & Q1. This is a religious place & 1.6 & 6.3 & 12.6 & 34.6 & 45.0 & .04982 & .97366 \\
\hline & Q2. This is just a tourist place for sightseeing & 14.1 & 30.9 & 19.9 & 18.3 & 16.8 & .06724 & 1.3141 \\
\hline & Q3. This is a historic and legendary place & 2.1 & 1.6 & 11.0 & 29.8 & 55.5 & .04563 & .89177 \\
\hline
\end{tabular}

Source: Author's calculations

Section three of the questionnaire comprised of three questions identifying the 'pull' motives. Based on the experiential approach, we identified three factors that may attract tourists to visit Ohrid: cultural heritage, religion and sightseeing. After analyzing the results, it was found that the cultural heritage was perceived as attraction that brought tourists to the surveyed locations. This finding stands along with the second most tourist type being identified for Ohrid.

There are many academic investigations that have identified political instability as a factor that may increase the perception of a risk at a destination [4], [6], [7], [11], [12], [15], [16], [18], [20] and [21]. In this line, the fourth section of the questionnaire encompassed three questions diagnosing tourist perception for safety. Ohrid (as tourist place) and Macedonia (as a country) were perceived as fully safe and secure for tourism. Even more, the total of $75 \%$ of the respondents disagree (39\% strongly disagree and $36 \%$ disagree) that they hesitated to come because it appeared in the news that this is a country with security problems.

Table 3. Summarized results referring tourist typology

\begin{tabular}{|c|c|c|c|c|c|c|c|c|}
\hline \multirow[b]{2}{*}{.0ّ } & \multirow[b]{2}{*}{ Specific questions } & \multicolumn{5}{|c|}{$\%$} & \multirow[b]{2}{*}{ 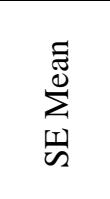 } & \multirow[b]{2}{*}{ 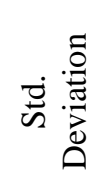 } \\
\hline & & 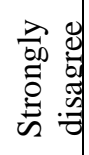 & $\begin{array}{l}\mathscr{D} \\
\underset{0}{0} \\
\stackrel{0}{0}\end{array}$ & $\begin{array}{l}\bar{\pi} \\
\stackrel{\Xi}{0} \\
\ddot{Z}\end{array}$ & 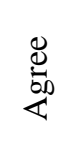 & 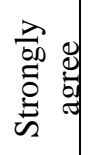 & & \\
\hline \multirow{5}{*}{ 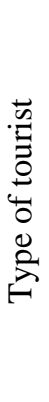 } & $\begin{array}{l}\text { Q10. I came here to enjoy myself (recreational } \\
\text { tourist) }\end{array}$ & 1.0 & 11.5 & 22.5 & 26.7 & 38.2 & .05497 & 1.0744 \\
\hline & $\begin{array}{l}\text { Q11. I feel as if this visit has changed my life } \\
\text { (diversionary tourist) }\end{array}$ & 11.5 & 21.5 & 33.0 & 21.5 & 12.6 & .06045 & 1.1814 \\
\hline & $\begin{array}{l}\text { Q12. I feel motivated and inspired here } \\
\text { (experiential tourist) }\end{array}$ & 2.6 & 8.9 & 25.1 & 37.2 & 26.2 & .05235 & 1.0231 \\
\hline & $\begin{array}{l}\text { Q13. I came here to learn something about local } \\
\text { people (experimental tourist) }\end{array}$ & 4.2 & 14.1 & 30.9 & 27.7 & 23.0 & .05715 & 1.1170 \\
\hline & $\begin{array}{l}\text { Q14. I came here to learn more about the lifestyle } \\
\text { and culture of this place (existential tourist) }\end{array}$ & 4.7 & 7.3 & 26.7 & 31.4 & 29.8 & .05652 & 1.1045 \\
\hline
\end{tabular}

Source: Author's calculations

Section five of the questionnaire had a set of five questions defining tourist type (based on classification proposed by Cohen [3]. Table 3 presents summarized findings. The results revealed that recreational tourists are by far the dominant group visiting Ohrid. Namely, $38.2 \%$ of the respondents strongly agree that came to enjoy themselves. Having in mind that this type of tourists put the emphasis on physical recreation, it is fully expectable that they will dominate due to the type of tourism Ohrid offers (sun, lake and leisure).
This is followed by the existential type of tourists whose main characteristic is that they want to

become totally immerse in the lifestyle of the vacation destination. In this line, $29.8 \%$ responded that strongly agreed that they came to Ohrid to learn more about the culture of Ohrid. This finding confirms the already acknowledged fact that Ohrid is a cultural cradle and with the cultural heritage it possesses, attracts cultural tourists in large portion. A light step behind are the experiential type of tourists, whereas $26.2 \%$ of respondents strongly 
agree that they feel motivated and inspired at the place of survey. This is also expected finding since experiential tourists look for authentic experiences, and the sampled locations (St. Naum and Plaosnik) are really unique spots.

Experimental tourists, whose main desire is to be in contact with local people, responded that they visited Ohrid in order to learn something about local people (23\%). Having in mind the rich history of the city, the specific artistic spirit along with numerous crafts (woodcarving, jewelry, pearl making, pottering, coppersmiths, shoemakers, etc.), still being performed in a traditional and original manner, attracts this type of tourists as well.

As the final tourist type, the research investigated whether Ohrid attracts diversionary tourists. It was found that they were virtually absent due to insignificant presence of only $12.6 \%$. This type of tourists seek way of forgetting their everyday life at home.

The last, sixth section of the questionnaire included three questions describing fulfilled expectations. The respondents found highly fulfilled expectations, thus evaluating Ohrid as a destination worth visiting which gave a value to their money.

Namely, $72 \%$ strongly agreed that the sampled location was worth visiting and if adding the responses "agreed" (22\%), it may be concluded that
94\% actually were delighted and enchanted of Ohrid. Furthermore, $42 \%$ strongly agreed and 29\% agreed, meaning that $71 \%$ of the respondents got more than expected. Finally, $61 \%$ strongly agreed and $27 \%$ agreed, or all together $88 \%$ of respondents would like to come back again and visit Ohrid. This supports the previous fact where it was noted that $45 \%$ visited Ohrid form more than five times. Simultaneously, it gives good prospects that the newcomers would come again.

\section{Cross-tabulations}

This part discusses the main findings upon the cross-tabulations of general data versus specific data (Table 4). It illustrates the association between categorical variables i.e. whether the variables are mutually independent or correlated. Due to fact that the calculated p-value is lower than the standard significance level $(\alpha=0.05)$, we reject the null hypothesis. Therefore, we conclude that there is enough evidence to suggest that there is statistically significant association between the variables. Yet, no inferences about the causation can be provided.

Table 4. Summarized results of the cross-tabulations general vs. specific data

\begin{tabular}{|c|c|c|}
\hline General data & Question & $\chi^{2}(\mathrm{p}$-value $)$ \\
\hline \multirow{5}{*}{ Gender } & Q4. I came here... cultural heritage attractions & .012 \\
\hline & Q6. I came here just for sightseeing & .054 \\
\hline & Q15. This place is worth visiting & .012 \\
\hline & Q16. I've got more than expected from this place & .004 \\
\hline & Q17. I would like to visit this place again & .001 \\
\hline \multirow{15}{*}{ Age } & Q1. This is a religious place & .001 \\
\hline & Q2. This is just a tourist place for sightseeing & .000 \\
\hline & Q3. This is a historic and legendary place & .000 \\
\hline & Q4.I came here... cultural heritage attractions & .000 \\
\hline & Q5. I came here for religious reasons & .015 \\
\hline & Q6. I came here just for sightseeing & .041 \\
\hline & Q7. The place is fully safe and secure for tourism & .000 \\
\hline & Q8. The country is fully safe and secure for tourism & .000 \\
\hline & Q9. I hesitated to come ... security problems & .015 \\
\hline & Q10. Recreational tourist & .005 \\
\hline & Q11. Diversionary tourist & .000 \\
\hline & Q12. Experiential tourist & .000 \\
\hline & Q13. Experimental tourist & .013 \\
\hline & Q15. This place is worth visiting & .001 \\
\hline & Q17. I would like to visit this place again & .000 \\
\hline \multirow{9}{*}{ Marital status } & Q1. This is a religious place & .009 \\
\hline & Q2. This is just a tourist place for sightseeing & .000 \\
\hline & Q3. This is a historic and legendary place & .000 \\
\hline & Q4. I came here... cultural heritage attractions & .003 \\
\hline & Q5. I came here for religious reasons & .000 \\
\hline & Q6. I came here just for sightseeing & .002 \\
\hline & Q7. The place is fully safe and secure for tourism & .004 \\
\hline & Q8. The country is fully safe and secure for tourism & .000 \\
\hline & Q9. I hesitated to come ... security problems & .000 \\
\hline
\end{tabular}




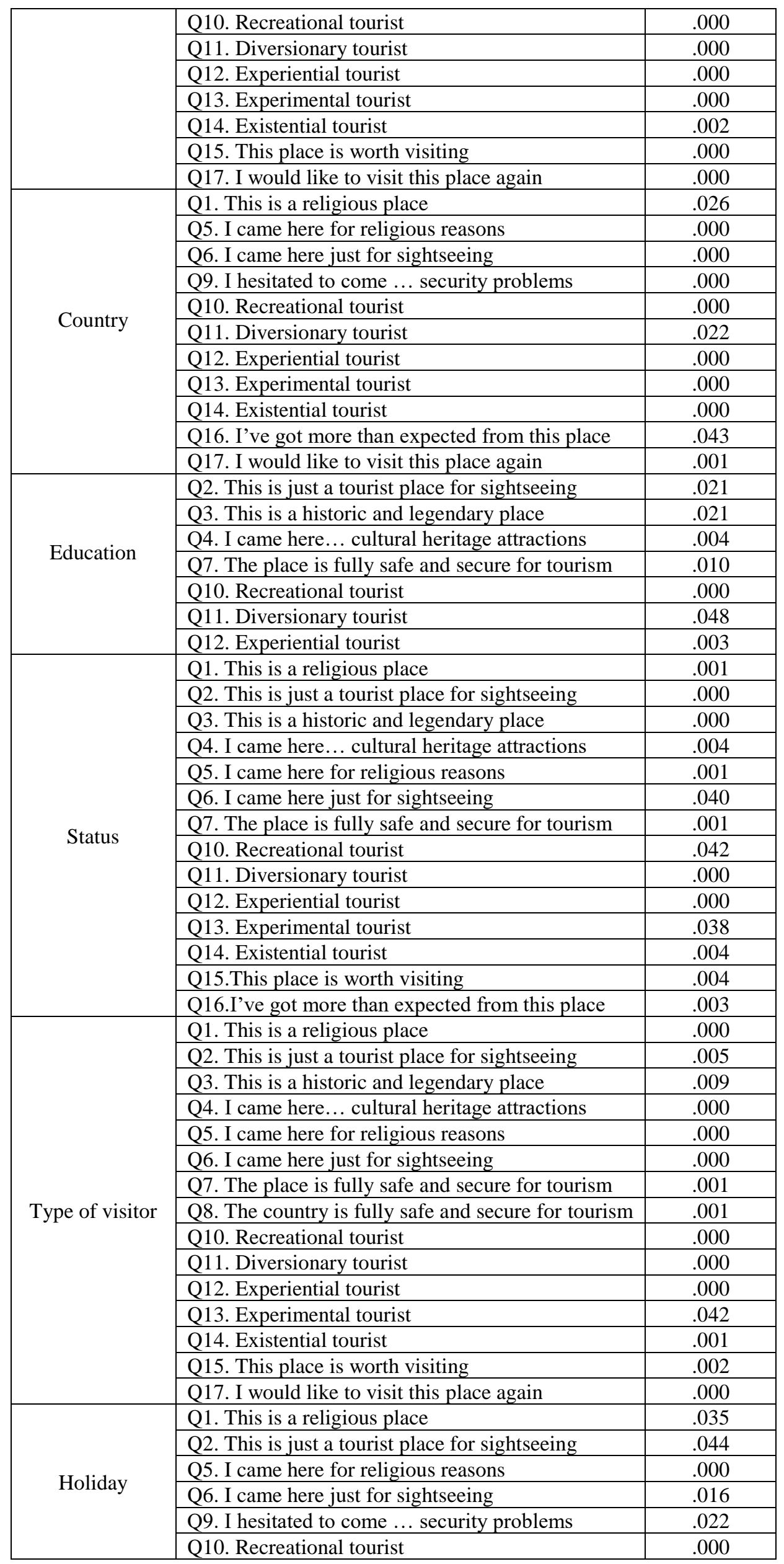




\begin{tabular}{|l|l|l|}
\hline \multirow{5}{*}{} & Q12. Experiential tourist & .011 \\
\cline { 2 - 3 } & Q13. Experimental tourist & .004 \\
\cline { 2 - 3 } & Q14. Existential tourist & .031 \\
\cline { 2 - 3 } & Q16. I've got more than expected from this place & .019 \\
\hline \multirow{5}{*}{ Frequency } & Q1. This is a religious place & .000 \\
\cline { 2 - 3 } & Q3. This is a historic and legendary place & .001 \\
\hline & Q4. I came here... cultural heritage attractions & .007 \\
\hline & Q5. I came here for religious reasons & .000 \\
\cline { 2 - 3 } & Q6. I came here just for sightseeing & .000 \\
\cline { 2 - 3 } & Q7. The place is fully safe and secure for tourism & .000 \\
\cline { 2 - 3 } & Q8. The country is fully safe and secure for tourism & .000 \\
\cline { 2 - 3 } & Q9. I hesitated to come ... security problems & .003 \\
\cline { 2 - 3 } & Q10. Recreational tourist & .000 \\
\cline { 2 - 3 } & Q11. Diversionary tourist & .001 \\
\cline { 2 - 3 } & Q12. Experiential tourist & .000 \\
\cline { 2 - 3 } & Q13. Experimental tourist & .031 \\
\cline { 2 - 3 } & Q14. Existential tourist & .000 \\
\cline { 2 - 3 } & Q15. This place is worth visiting & .000 \\
\hline & Q17. I would like to visit this place again & \\
\hline
\end{tabular}

Note: Only data with a significance $\mathrm{p}<0.05$ are presented

to the destination. However being domestic or a

Based upon the calculations presented in Table 4, we find enough evidence to suggest that there is association between the nine variables of general data (gender, age, marital status, country of origin, education, occupational status, type of visitor, type of holiday, and frequency of visit) and some specific data. In this line, statistically significant association is found as follows:

- With regards to the gender, both male, and female tourists not equally prefer the same pull motives and fulfilled expectations;

- As per age, the association is found almost in all investigated issues. This means that the age makes difference, since all three categories (younger tourists between 20-29 years, mature tourists between 30-49 years, and older tourists being over 50 years) responded differently. There are only two exceptions noted. Namely, there is no correlation between age and the existential type of tourist (Q14) as well as between age and the return to place (Q16);

- Presence of association is assessed between marital status and all, but one questioned issue (Q16). So, whether the tourist is married, single, divorced, live with a partner, or even replied as 'other', makes a difference to all investigated issues, with the exception of 'getting more than expected from the place'. This means that the marital status is not correlated only to this specific aspect defining the returning to the place;

- Being domestic or a foreign tourist (as per country of origin) makes statistically significant relations to perceiving the sampled location as a religious place, being attracted by religious or - sightseeing motives, tourist typology, and return foreign tourist does not make a difference to the perception for safety;

- Education (tourists with elementary, high school or faculty education) is related to seven out of seventeen investigated queries. The type of education is correlated with the majority of tourist types (recreational, diversionary and experiential) along with the motives that create a perception of place. The education is associated to the cultural heritage as a pull motive that attracts tourists to visit the destination, the same as the destination's perception for safety;

- Occupational status is correlated with all the specific investigated issues, except for the perception on the safety of the country (Q8 and Q9). So, students, employed, unemployed and retired tourists equally perceive Macedonia as safe tourist destination;

- The type of visitor is generally related to all the specific issues. The exception is noted with regards the "hesitation to come because it appears in the news that Macedonia has security problems' (Q9) and 'got more than expected' (Q16). So, whether respondents declared as pilgrims, tourists or 'other', makes no difference only in these two queries;

- Visiting Ohrid individually (self-organized) or in a group (by travel agency) is related to perceiving Ohrid as religious and tourist place, but not as historic and legendary place. The type of holiday makes no difference when it comes to the safety perception of Ohrid (place) and Macedonia (country), the same as in the case of creating an image for fulfilled expectations; and 
- Frequency of visit i.e. visiting Ohrid for the first time, second time, 3-5 times, or more than five times, has an influence when creating a tourist image for Ohrid. Generally, there is an association between the variables, with just only one exception. According to the frequency of visit, tourists equally find to get more than expected.

Table 5. Summarized results on presence of independency, general vs. specific data

\begin{tabular}{|c|l|}
\hline General data & Specific data (grouped queries) \\
\hline \multirow{4}{*}{ Gender } & Perception of place (Q1-Q3) \\
\cline { 2 - 2 } & Pull motives (Q4-Q6) \\
\cline { 2 - 2 } & Perception for safety (Q7-Q9) \\
\cline { 2 - 2 } Country of origin & Tourist type (Q10-Q14) \\
\cline { 2 - 2 } & Perception of place (Q1-Q3) \\
\cline { 2 - 2 } Education & Perception for safety (Q7-Q9) \\
\hline & Pull motives (Q4-Q6) \\
\cline { 2 - 2 } & Perception for safety (Q7-Q9) \\
\hline Occupational status & Perception for safety (Q7) \\
\hline \multirow{3}{*}{ Type of holiday } & Perception for safety (Q7-Q9) \\
\cline { 2 - 2 } & Return to place (Q15-Q17) \\
\hline
\end{tabular}

Source: Author's calculations

Note: Summarized results for data with a significance $p>0.05$

More general conclusions from the cross tabulations are presented in Table 5 referring to independency of the variables. It is noticeable that gender is by far the most independent variable, followed by education, country of origin, type of holiday and occupational status. Namely, as presented in Table 5, it can be concluded that 'perception for safety' is a strongly independent factor when creating tourism image. On the other side, it was found that:

- Gender matters when it comes to the fulfilled expectations (return to place);

- Country of origin matters when it comes to the pull motives, tourist type and fulfilled expectations;

\section{CONCLUSION AND RECOMMENDATIONS}

Based upon the field work and findings, the study recommends some future actions in the line of creating new strategic approaches that may support tourism development in Ohrid. First, efforts should be made to make tourism fully recognizable and to improve the current marketing strategy. The focus should be on promotion, mainly through the introduction of new innovative approaches. The second strategic measure recommended for improving tourism competitiveness is to strengthen the coordination between the central and local governments, in addition to other tourism players from the private sector. The objectives and aims delineated by the tourism development plans and programs must be fully implemented, regardless of the level of implementation. The expectations of all tourism suppliers must conform to the expectations of tourists and travelers who visit Ohrid. By combining the insights from earlier works, the
- Type of education matters when it comes to the perception of place and tourist type;

- Occupational status matters when it comes to perception of place, pull motives, tourist type and return to place; and

- Type of holiday matters when it comes to perception of place, pull motives and tourist type. Furthermore, based on the established correlation patterns, it can be summarized that the variables like: age, marital status, type of visitor and frequency are statistically dependent categories. This means that tourism policy makers should have in mind to make tourism segmentation particularly taking into consideration these criteria when creating tourism policy and development strategy. study identified and explored the presence of five factors, upon which tourists create images and

perceptions for Ohrid. It was found that Ohrid is perceived as historic, legendary and religious place and not just as a plane tourist destination, whereas the cultural heritage is the main pull factor for attracting tourists. Towards the perception for safety, both, Ohrid (as tourist place) and Macedonia (as a country), were perceived as fully safe and secure for tourism. According to the type of experience, the recreational tourists are by far the most present. Being described as destination worth visiting which gave a value to their money, tourists found to have highly fulfilled expectations from Ohrid as a destination.

Furthermore, it was found that gender is by far the most independent variable meaning that generally both male, and female tourists equally create tourism image of Ohrid. This is followed by 
education, whereas it was found that it is irrelevant where the tourist has elementary, high school or faculty diploma. What is especially interesting is that both domestic and foreign tourists in general perceive the same Ohrid as a destination when it comes to its perception of place and safety.

Likewise, variables like: age, marital status, type of visitor and frequency, are totally statistically dependent, pointing to be used as segmentation criteria when defining tourism development strategy. So, younger tourists create different perception for Ohrid, compared to mature and older

\section{LIMITATIONS AND FUTURE WORK}

The research was limited by several factors that can also serve as productive starting points for future work. First, it employed a relatively small set of indicators and could be enhanced by the addition of additional significant indicators to better assess tourists' perception. Because data was collected using only a questionnaire survey, the research may also suffer from the common method variance tourists. This is also the case if tourists replied as married, single, divorced, live with a partner, or even 'other'. If respondents declared as pilgrims, tourists or 'other', makes difference to creating a tourist image of Ohrid. According to the frequency of visit, tourists does not equally experience Ohrid. Yet, due to fact that the calculated values of the nonparametric tests assess only association between the variables without providing inferences about the causation, it is up to tourism experts to interpret them accordingly.

effect. As the research was characterized by a relatively small sample size, future work could focus on increasing the number of respondents and other aspects of investigation. Finally, instead of using one model, future research could employ multiple models and theories relevant to tourism imaging.

\section{REFERENCES}

[1] Beard, J. G. \& Ragheb, M. G. (1983). Measuring leisure motivation. Journal of leisure research, 15, 219-228.

[2] Cohen, E. (1972). Towards a sociology of international tourism. Social Research, 39, 164-182.

[3] Cohen, E. (1979). A phenomenology of tourist experience. Sociology 13(2), 179-201.

[4] Gartner, W. \& Shen, J. (1992). The Impact of Tiananmen Square on China's Tourism Image. Journal of Travel Research, 30(4), 47-52.

[5] Gibson, H. \& Yiannakis, A. (2002). Tourist roles: Needs and the lifecourse. Annals of Tourism Research, 29(2), 358383.

[6] Hollier, R. (1991). Conflict in the Gulf. Tourism Management, 12, 2-4.

[7] Ioannides, D. \& Apostolopoulos, Y. (1999). Political Instability, War and Tourism in Cyprus: Effects, Management and Prospects for Recovery. Journal of Travel Research, 38(1), 51-56.

[8] Jiang, J., Havitz, M. \& O’Brien, R. (2000). Validating the International Tourist Role Scale. Annals of Tourism Research, 27, 964-981.

[9] Keng, K. \& Cheng, J. (1999). Determining Tourist Role Typologies: An Exploratory Study of Singapore Vacationers. Journal of Travel Research, 37(4), 382-391.

[10] Lepp, A. \& Gibson, H. (2003). Tourist roles, perceived risk and international tourism. Annals of Tourism Research, $30(3), 606-624$.

[11] Mansfeld, Y. (1996). Wars, Tourism and the "Middle East" Factor. In Tourism, Crime and International Security Issues (A. Pizam and Y. Mansfeld, eds.), pp. 265-278. New York: Wiley.

[12] Mansfeld, Y. (1999). Cycles of War, Terror and Peace: Determinants and Management of Crisis and Recovery of the Israeli Tourism Industry. Journal of Travel Research, 38(1), 30-36.

[13] Mo, C., Howard, D. R. \& Havitz, M. E. (1992). Testing an international tourist role typology. Annals of Tourism Research, 20, 319-335.

[14] Pearce, P. (1982). The social psychology of tourist behaviour. New York: Pergamon.

[15] Richter, L. (1992). Political Instability and Tourism in the Third World. In Tourism and the Less Developed Countries, (D. Harrison, ed.), pp. 35-46. New York: Wiley.

[16] Richter, L. (1999). After Political Turmoil: The Lessons of Rebuilding Tourism in Three Asian Countries. Journal of Travel Research, 38(1), 41-45.

[17] Ryan, C. \& Glendon, I. (1998). Application of leisure motivation scale to tourism. Annals of Tourism Research, 25(1), $169-184$. 
[18] Seddighi, H., Nuttall, M. \& Theocharous, A. (2001). Does Cultural Background of Tourists Influence the Destination Choice? An Empirical Study with Special Reference to Political Instability. Tourism Management, 22, $181-191$.

[19] State Statistical Office of the Republic of Macedonia. (2017). Statistical Yearbook for 2016, Skopje.

[20] Teye, V. (1986). Liberation Wars and Tourism Development in Africa: The Case of Zambia. Annals of Tourism Research, 13, 589-608.

[21] Wall, G. (1996). Terrorism and Tourism: An Overview and an Irish Example. In Tourism, Crime and International Security Issues, (A. Pizam and Y. Mansfeld, eds.), pp. 143-158. New York: Wiley.

[22] Yiannakis, A. \& Gibson, H. (1992). Roles Tourist Play. Annals of Tourism Research, 19, 287-303.

[23] Yfantidou, G., Costa, G. \& Michalopoulos, M. (2008). Tourist roles, gender and age in Greece: a study of tourists in Greece. International Journal of Sport Management Recreation \& Tourism, 1, 14-30. 